\title{
The relationship of estrus character before double dose artificial insemination in Limousin Crossbred cow
}

\author{
Putri Utami ${ }^{1}$, Muhammad Zainul Hanif ${ }^{1}$, Aulia Puspita Anugra Yekti $^{2}$, Joko Riyanto ${ }^{3}$, \\ Chusnul Hanim ${ }^{4}$, and Trinil Susilawati ${ }^{2 *}$ \\ ${ }^{1}$ Post Graduate Programe Faculty of Animal Science, Universitas Brawijaya, Malang, Indonesia \\ ${ }^{2}$ Faculty of Animal Science, Universitas Brawijaya, Malang, Indonesia \\ ${ }^{3}$ Faculty of Agriculture, University of Sebelas Maret, Surakarta, Indonesia \\ ${ }^{4}$ Faculty of Animal Science, University of Gadjah Mada, Yogyakarta, Indonesia
}

\begin{abstract}
Ongole cattle in smallholder farms on Java, Indonesia, have been crossed with Limousin, which is not controlled repeatedly. The character of estrus affects the success of Artificial Insemination. This study aimed to determine the relationship between estrus characters before double dose artificial insemination using frozen semen sexing. The research was conducted in Senggreng Village, Sumber Pucung District, Malang Regency. The material was 45 head of Limousin crossbred cow inseminated using sexing semen produced by the Singosari National Artificial Insemination Center (SNAIC). The sexed semen processed with the Percoll Density Gradient Centrifugation (PDGC) method. The average body value of cows between 3-5 (scale 1-9) with an average age of 1.8-7 years, normal reproduction, clear signs of estrus. The reproductive organs were examined by rectal palpation to confirm that the cows are not pregnant. Parameters of estrus character were vulvar color, cervical mucus, vaginal temperature, $\mathrm{pH}$, vulvar swelling, and heat detector value. The result showed that the estrus characters, including vulva color, vulva swelling, cervical mucus, vaginal temperature, cervical mucus $\mathrm{pH}$, and heat detector score in the first and second artificial insemination have a low relationship. The regression models produced can be used but are less precise to estimate the relationship between estrus characters because the coefficient of determination shows a low influence.
\end{abstract}

\section{Introduction}

Beef cattle on smallholder farms have been crossed with limousine or Simental cattle repeatedly with a low success rate of pregnancy and high service per conception, which is more than two times insemination to conceive successfully [1]. Artificial insemination (AI) is one of the reproductive technologies widely applied in smallholder farms to increase

\footnotetext{
* Corresponding author: tsusilawati@ub.ac.id
} 
cattle productivity by utilizing superior male spermatozoa, thereby increasing the number of offspring quickly [2].

The timing of AI is one of the factors that influence the success of pregnancy in livestock. The appearance of signs of estrus becomes a guideline for artificial insemination. Human resources, especially breeders and inseminators, need to detect estrus in one period of the estrus cycle so that they can determine the best time for AI [3]. Detection and observation of estrus character are one essential factor in determining the success of pregnancy. Cows in estrus will show characters such as a reddened, swollen vulva, increased body temperature, slimy (mucus or mucus coming from the cervix is transparent or clear in color). When a male ride it, it will remain silent [4]. The accuracy of detection is related to the time of artificial insemination. Lack of farmers' knowledge in detecting estrus can affect the delay in insemination time, resulting in pregnancy failure. The success of mating pregnancy can be evaluated through the reproductive efficiency of female cattle. To assess the success of pregnancy, it can be known through several parameters, namely the conception rate (CR) and pregnancy rate (PR) [5]. Based on the description above, it is essential to know the relationship between estrus characters, which can later be used to determine the time of Artificial Insemination.

\section{Materials and methods}

The study was conducted from March $5^{\text {th }} 2021$, to June $20^{\text {th }} 2021$. The post-thawing spermatozoa quality test was carried out at the Reproductive Laboratory of the Faculty of Animal Husbandry, Universitas Brawijaya, Malang and the AI in Senggreng Village, Sumber Pucung District, Malang Regency, East Java. The material used in this study was 45 female Limousin Crossbred cow which were artificially inseminated using sexed semen produced by Singosari National Artificial Insemination Center (SNAIC). The material were selected based on the average body value between 3-5 (scale 1-9) with age 1.8-7 years old had a health condition, showed signs of heat, and their reproductive organs were examined by rectal palpation so that the acceptors were confirmed to be in unpregnant.

The method used in this study is an experimental method with a field experiment. The sampling technique used the purposive sampling method. The artificial insemination technique is done with $4+$ deposition (cornua uteri). Insemination used a double dose at the $2^{\text {nd }}$ (first $\mathrm{AI}$ ) and $8^{\text {th }}$ hours (second $\mathrm{AI}$ ) after estrous, and injection of "Rheinbio" as BioATP+. Observations of estrus characters included vulvar color, vulvar swelling, cervical mucus, vulvar temperature, cervical mucus $\mathrm{pH}$, and heat detector values. The observation process of the estrus character was carried out before the first and second artificial insemination.

The data obtained from the study results were the estrus character of livestock before the first and second artificial insemination. Data were analyzed using the simple linear regression correlation analysis method using Microsoft Excel software. Correlation analysis was used to find the direction and strength of the relationship between two variables. In contrast, regression analysis predicts how far the value changes between variables when it changes up or down. Simple linear regression analysis was used to find a regression line between two variables, namely $\mathrm{X}$ and $\mathrm{Y}$, described in coordinate points [6]. 
Table 1. Description of Estrus Characteristic

\begin{tabular}{|l|l|}
\hline Parameters & Description \\
\hline Vulva color (reddening vulva) & $\begin{array}{l}\text { The appearance of vulva are assessed by a modified } \\
\text { score consisting of: evenly red with a score of 3, } \\
\text { uneven red (pink) with a score of 2, and pale with a } \\
\text { score of 1 [7]. }\end{array}$ \\
\hline Swelling vulva & $\begin{array}{l}\text { Swelling of the vulva was assessed by a modified } \\
\text { score consisting of: very swollen with a score of 3, } \\
\text { slightly swollen with a score of 2, and not swollen } \\
\text { with a score of 1 [7]. }\end{array}$ \\
\hline Cervical mucus & $\begin{array}{l}\text { Cervical mucus is assessed by a modified score } \\
\text { consisting of: There is a lot of mucus with a score } \\
\text { of 3, there is a little mucus with a score of 2, and } \\
\text { the mucus is dry or none with a score of 1 [8]. }\end{array}$ \\
\hline Vaginal temperature & $\begin{array}{l}\text { Vaginal temperature before AI was measured using } \\
\text { a thermometer [7] }\end{array}$ \\
\hline pH & $\begin{array}{l}\text { Measurement of the pH of cervical mucus is done } \\
\text { using litmus paper which will be expressed in the } \\
\text { range 1-12 [7] }\end{array}$ \\
\hline Heat detectors & $\begin{array}{l}\text { Heat detectors the measurement results of the heat } \\
\text { detector value will appear in the form of numbers } \\
0-60 \Omega \text { [9]. }\end{array}$ \\
\hline
\end{tabular}

\section{Results and discussion}

\subsection{Relationship Between Cervical Mucus and Heat Detector Value Before The First And Second Al}

Table 2. Percentage of cattle on each character of criteria servical mucus and heat detector value before first AI

\begin{tabular}{|l|c|c|c|}
\hline $\begin{array}{l}\text { Condition servical } \\
\text { mucus before first AI }\end{array}$ & Head (\%) & $\begin{array}{c}\text { Heat detector value } \\
\text { in first AI }\end{array}$ & Head (\%) \\
\hline Abundant & $3(6,67)$ & $20-29$ & $45(100)$ \\
\hline Moderate & $34(75,56)$ & $30-40$ & $0(0)$ \\
\hline Low/Absent & $8(17,78)$ & & $45(100)$ \\
\hline Total & $45(100)$ & Total & \\
\hline
\end{tabular}

Table 3. Percentage of cattle on each character of criteria servical mucus and heat detector value before second AI

\begin{tabular}{|l|c|c|c|}
\hline $\begin{array}{l}\text { Condition servical } \\
\text { mucus before second AI }\end{array}$ & Head (\%) & $\begin{array}{c}\text { Heat detector value } \\
\text { in second AI }\end{array}$ & Head (\%) \\
\hline Abundant & $18(40,00)$ & $25-29$ & $43(95,56)$ \\
\hline Moderate & $24(53,33)$ & $30-40$ & $2(4,44)$ \\
\hline Low/Absent & $3(6,67)$ & & $45(100)$ \\
\hline Total & $45(100)$ & Total & 4 \\
\hline
\end{tabular}

Based on the analysis of variance results, it can be concluded that the linear regression equation of the relationship between cervical mucus and value of heat detectors in the first and second $\mathrm{AI}$ is not significant $(\mathrm{P}>0.05)$. The regression analysis results showed the correlation coefficient ( $\mathrm{r}$ ) of cervical mucus and the value of cow heat detector in the first and second artificial insemination were -0.158 and -0.087 , which had a low level of 
relationship. The direction of the resulting relationship is negative. The coefficient of determination was $2.508 \%$, meaning that the heat detector value was determined by cervical mucus in the first artificial insemination and the second by $0.763 \%$. In comparison, $97.492 \%$ and $99.237 \%$ were determined by other factors. The regression analysis results using the significance level (0.05) indicate that this regression model can be used. Still, it is not appropriate to estimate the impacts of the relationship between cervical mucus and heat detector because the results of the coefficient of determination show a common effect. The estradiol from mature de Graff follicles in estrus conditions would cause changes in the maximum tubular reproductive tract. The condition of the uterus becomes tense, and cervical mucus secretion increases. High levels of the hormone estrogen affect vaginal vasodilation so that the volume of cervical mucus secreted by goblet cells will increase. The appearance of cervical mucus changes during estrus. These changes include a transparent appearance at the beginning of estrus, gradually cloudy in the middle of estrus, and clear and shiny at the end of estrus [10]. Cervical mucus has relatively high conductivity, so that the volume of cervical mucus has an increasing effect on the lower electrical resistance produced [11]. The lower electrical resistance means that the value that appears on the screen of the heat detector shows a small number ranging from 30-40 [9]. The numbers displayed on the screen of the heat detector indicate that the volume of cervical mucus produced is relatively large. The hormone estrogen level in the blood increases, and the cattle are in the estrus phase.

\subsection{Relationship Between Cervical Mucus and Vaginal Temperature Before The First And Second Al}

Table 4. Percentage of cattle on each character criteria of servical mucus and vaginal temperature before first AI

\begin{tabular}{|l|c|c|c|}
\hline $\begin{array}{l}\text { Condition servical } \\
\text { mucus before first AI }\end{array}$ & Head (\%) & $\begin{array}{c}\text { Vaginal temperature } \\
\text { before first AI }\end{array}$ & Head (\%) \\
\hline Abundant & $3(6,67)$ & $37-38,5$ & $33(73,33)$ \\
\hline Moderate & $34(75,56)$ & $>38,5$ & $12(26,67)$ \\
\hline Low/Absent & $8(17,78)$ & & $45(100)$ \\
\hline Total & $45(100)$ & & \\
\hline
\end{tabular}

Table 5. Percentage of cattle on each character criteria of servical mucus and vaginal temperature before second AI

\begin{tabular}{|l|c|c|c|}
\hline $\begin{array}{l}\text { Condition servical } \\
\text { mucus before second AI }\end{array}$ & Head (\%) & $\begin{array}{c}\text { Vaginal temperature } \\
\text { before second AI }\end{array}$ & Head (\%) \\
\hline Abundant & $18(40)$ & $37-38,5$ & $25(55,56)$ \\
\hline Moderate & $24(53,33)$ & $>38,5$ & $20(44,44)$ \\
\hline Low/Absent & $3(6,67)$ & & $45(100)$ \\
\hline Total & $45(100)$ & & \\
\hline
\end{tabular}

Based on the analysis of variance results, it can be concluded that the linear regression equation of the relationship between cervical mucus and vaginal temperature in the first and second artificial insemination was not significant $(\mathrm{P}>0.05)$. The analysis results showed that the level of closeness between cervical mucus and vaginal temperature in the first and second AI was -0.164 and 0.045 . The direction of the relationship produced by cervical mucus in the first AI was negative, and in the second AI was positive. The regression analysis results using the significance level (0.05) indicate that this regression model can be used. Still, it is not appropriate for estimating the relationship between cervical mucus and vaginal temperature because the coefficient of determination shows a common effect. The 
coefficient of determination was $2.703 \%$, meaning that the vaginal temperature was determined by cervical mucus in the first AI $2.703 \%$ and the second at $0.205 \%$, while other factors decided $97.297 \%$ and $99.795 \%$.

Environmental factors are one of the factors that influence changes in vaginal temperature. Temperature changes could be caused by increased livestock activity during estrus because $\mathrm{GnRH}$ and estradiol influence the central regulation of body temperature. In addition, housing management can also have an effect so that the cattle's space is limited and results in a significant increase in body temperature during estrus. However, infection or unhealthy livestock conditions, especially after calving, can affect the temperature observed around estrus. An increase in temperature in livestock under unsanitary conditions can be mistaken for an increase in estrus. High levels of the hormone estrogen during estrus cause the blood vessel network to multiply by developing the reproductive tract. At the same time, estrogen increases blood flow to the reproductive tract, resulting in a high vulvar temperature [12]. Cow's vagina in each estrus phase showed a difference. The diestrus phase is $37.40^{\circ} \mathrm{C}$, and the proestrus phase is $37.86^{\circ} \mathrm{C}$; in the estrus phase, the highest temperature is $38.39^{\circ} \mathrm{C}$, and the metestrus phase is $38.05^{\circ} \mathrm{C}$. At the time of estrus, more increased blood flow flows into the reproductive tract, which causes the temperature to increase. The highest average vaginal temperature was obtained at the time of estrus. Changes in vaginal temperature occur due to the vascularization process involving the hormone estrogen. The blood vessels become full, accompanied by thermal flowing along with the increase in vaginal temperature. In addition, the consistency of cervical mucus varies in each cycle, and the cervix provides the energy (glucose) needed for the movement of spermatozoa after they are separated from the semen. Cervical mucus during estrus, besides being a medium for spermatozoa to reach the site of fertilization, also functions as a selector for spermatozoa [13].

\subsection{Relationship Between The Color Of The Vulva and Ph of Cervical Mucus Before The First and Second Al}

Table 6. Percentage of cattle on each character criteria of the vulva color and $\mathrm{pH}$ cervical mucus before first AI

\begin{tabular}{|l|c|c|c|}
\hline $\begin{array}{l}\text { The color of the vulva } \\
\text { before first AI }\end{array}$ & Head (\%) & $\begin{array}{c}\text { pH of cervical mucus } \\
\text { before first AI }\end{array}$ & Head (\%) \\
\hline Evenly red & $15(33,33)$ & $6-7$ & $20(44,44)$ \\
\hline Uneven red (pink) & $19(42,22)$ & $7,1-8$ & $25(55,56)$ \\
\hline Pale & $11(24,44)$ & & \\
\hline Total & $45(100)$ & Total & $45(100)$ \\
\hline
\end{tabular}

Table 7. Percentage of cattle on each character criteria of the vulva color and $\mathrm{pH}$ cervical mucus before second $\mathrm{AI}$

\begin{tabular}{|l|c|c|c|}
\hline $\begin{array}{l}\text { The color of the vulva } \\
\text { before second AI }\end{array}$ & Head (\%) & $\begin{array}{c}\text { pH of cervical mucus } \\
\text { before second AI }\end{array}$ & Head (\%) \\
\hline Evenly red & $19(42,22)$ & $6-7$ & $20(44,44)$ \\
\hline Uneven red (pink) & $12(26,67)$ & $7,1-8$ & $25(55,56)$ \\
\hline Pale & $14(31,11)$ & & \\
\hline Total & $45(100)$ & Total & $45(100)$ \\
\hline
\end{tabular}

Based on the analysis of variance results, it can be concluded that the linear regression equation of the relationship between the color of the vulva and the $\mathrm{pH}$ of cervical mucus in the first and second AI was not significantly different $(\mathrm{P}>0.05)$. The regression analysis results showed that the correlation coefficient (r) between the color of the vulva and the $\mathrm{pH}$ 
of cow's cervical mucus in the first and second inseminations was 0.023 and 0.100 . The direction of the resulting relationship between the two in the first and second AI was positive. The coefficient of determination showed that the $\mathrm{pH}$ value of cervical mucus was determined by the color of the vulva in the first and second AI was $0.053 \%$ and $1.002 \%$, while other factors decided $99.947 \%$ and $98.998 \%$.

The degree of acidity $(\mathrm{pH})$ is an essential parameter of cervical mucus in sperm transfer into the reproductive tract of female cattle, and $\mathrm{pH}$ affects the viability of sperm in the cervix. During estrus, the cervix secretes mucus which has a $\mathrm{pH}$ of 6.6-7.5 in cattle [14]. The difference in the $\mathrm{pH}$ value of cervical mucus in each animal is influenced by biophysical and biochemical conditions of the mucus produced by the cervix, controlled by hormones that play a role in the estrus cycle [15]. The higher the estrogen hormone in the blood during estrus, the volume of cervical mucus will increase with an alkaline $\mathrm{pH}$. The hormone estrogen affects the increase in mucoprotein, sodium chloride, and cervical mucus levels, which change the $\mathrm{pH}$ of cervical mucus during estrus [16]. The alkaline $\mathrm{pH}$ of cervical mucus affects spermatozoa's motility, viability, and penetration power [17]. That each estrus cycle stage produces a different $\mathrm{pH}$ value. The presence of estrogen indicates that the ovarian cycle is functioning and the discharge of cervical mucus. Estrogen levels are closely related to cervical mucus, where the $\mathrm{pH}$ value of cervical mucus at the peak of estrus is more alkaline. This is because increased levels of the hormone estrogen affect sodium chloride levels that increase. The $\mathrm{pH}$ value of cervical mucus is closely related to the transport medium of spermatozoa. The $\mathrm{pH}$ value range of 7.0-8.5 is the optimal condition for the viability and motility of spermatozoa, and if the $\mathrm{pH}$ value is below 6 , it will decrease the motility of spermatozoa [18].

\subsection{Relationship Between The Color of The Vulva and Heat Detector Value Before The First and Second Al}

Table 8. Percentage of cattle on each character criteria of the vulva color and heat detector value before first AI

\begin{tabular}{|l|c|c|c|}
\hline $\begin{array}{l}\text { The color of the vulva } \\
\text { before first AI }\end{array}$ & Head (\%) & $\begin{array}{c}\text { Head detector value } \\
\text { before first AI }\end{array}$ & Head (\%) \\
\hline Evenly red & $15(33,33)$ & $20-29$ & $45(100)$ \\
\hline Uneven red (pink) & $19(42,22)$ & $30-40$ & $0(0)$ \\
\hline Pale & $11(24,44)$ & & $45(100)$ \\
\hline Total & $45(100)$ & Total & 4 \\
\hline
\end{tabular}

Table 9. Percentage of cattle on each character criteria of the vulva color and heat detector value before second AI

\begin{tabular}{|l|c|c|c|}
\hline $\begin{array}{l}\text { The color of the vulva } \\
\text { before second AI }\end{array}$ & Head (\%) & $\begin{array}{c}\text { Head detector value } \\
\text { before second AI }\end{array}$ & Head (\%) \\
\hline Evenly red & $19(42,22)$ & $25-29$ & $43(95,56)$ \\
\hline Uneven red (pink) & $12(26,67)$ & $30-40$ & $2(4,44)$ \\
\hline Pale & $14(31,11)$ & & \\
\hline Total & $45(100)$ & Total & $45(100)$ \\
\hline
\end{tabular}

Based on the analysis of varian result, the relationship between the color of the vulva and the heat detector in the first AI was not significant, and the second AI was significantly different $(\mathrm{P}<0.05)$. The regression analysis results showed that the correlation coefficient (r) between the color of the vulva and the heat detector of cows in the first and second AI was -0.174 and -0.311 . The direction of the resulting relationship between the two characters in the first and second AI was negative. The coefficient of determination value 
was $3.002 \%$ and $9.672 \%$, which means that the heat detector value was determined by the color of the vulva $3.002 \%$ and $9.672 \%$, while other factors determined $96.998 \%$ and $90.328 \%$.

Another factor that affects the value of the heat detector is the concentration of mucus. Changes in the heat detector value or low electric current resistance in vaginal mucus in estrus cattle conditions are caused by high hormone estrogen levels, resulting in vasodilation in the vagina and an increase in the number and volume of ions secreted by the vagina. These ions are electrolytes and have reasonably high conductivity, so that the more ions, the lower the electrical resistance produced [11]. Cervical mucus consists of protein, fat, cholesterol, sorbitol, reducing sugar, sodium, potassium, calcium, organic phosphorus, and chlorine [19]. The appearance of clear mucus in cattle under estrus is directly proportional to the low resistance. The low value of the resulting inhibition may be due to an increase in estrogen, which causes vasodilation in the vagina [17]. Cervical mucus can prevent the entry of microbes into the female reproductive tract and facilitate the transportation of spermatozoa. Cervical mucus changes from a small volume to become cloudy and thick in mid or late estrus. Variations in color, consistency, and volume of cervical mucus indicate the physiological properties of cervical mucus change during the estrus cycle [8].

\subsection{Relationship Between The Color of The Vulva and Swelling Vulva Before The First and Second Al}

Table 10. Percentage of cattle on each character criteria of the vulva color and swelling vulva before first AI

\begin{tabular}{|l|c|c|c|}
\hline $\begin{array}{l}\text { The color of the vulva } \\
\text { before first AI }\end{array}$ & Head (\%) & $\begin{array}{c}\text { Swelling vulva before } \\
\text { first AI }\end{array}$ & Head (\%) \\
\hline Evenly red & $15(33,33)$ & Very swollen & $26(57,78)$ \\
\hline Uneven red (pink) & $19(42,22)$ & Slightly swollen & $19(42,22)$ \\
\hline Pale & $11(24,44)$ & Not swollen & $0(0)$ \\
\hline Total & $45(100)$ & Total & $45(100)$ \\
\hline
\end{tabular}

Table 11. Percentage of cattle on each character criteria of the vulva color and swelling vulva before second AI

\begin{tabular}{|l|c|c|c|}
\hline $\begin{array}{l}\text { The color of the vulva } \\
\text { before second AI }\end{array}$ & Head (\%) & $\begin{array}{c}\text { Swelling vulva before } \\
\text { second AI }\end{array}$ & Head (\%) \\
\hline Evenly red & $19(42,22)$ & Very swollen & $26(57,78)$ \\
\hline Uneven red (pink) & $12(26,67)$ & Slightly swollen & $19(42,22)$ \\
\hline Pale & $14(31,11)$ & Not swollen & $0(0)$ \\
\hline Total & $45(100)$ & Total & $45(100)$ \\
\hline
\end{tabular}

Based on the analysis of variance results, it can be concluded that the linear regression equation of the relationship between vulvar color and vulvar swelling in the first and second AI was not significant $(\mathrm{P}>0.05)$. The regression analysis results showed that the correlation coefficient (r) between vulvar color and vulvar swelling of cows in the first AI was 0.101 and the second AI was 0.271 . The direction of the resulting relationship between the two characters is positive. The coefficient of determination values were $1.013 \%$ and $7.335 \%$, meaning that the value of vulvar swelling was determined by the color of the vulva $1.013 \%$ and $7.335 \%$, while other factors determined $98.987 \%$ and $92.665 \%$. The regression analysis results using the significance level (0.05) indicate that this regression model can be used but is not appropriate to estimate the impacts of the relationship between vulvar color and vulvar swelling because the coefficient of determination shows a common effect. 
Elevated levels of the hormone estrogen in the blood have been linked to changes in color and swelling of the vulva. The increase in the level of the estrogen hormone tends to occur when the cattle are in estrus. The hormone estrogen will stimulate the thickening of the vaginal wall and increase vascularization so that the vulva will swell and change color to reddish [20]. The condition of the hormone estrogen continues to increase when cattle estrus stimulates blood flow to the reproductive tract and related genital organs. This condition causes the blood vessel network to multiply according to the development of the reproductive tract. At the same time, estrogen increases blood flow to the reproductive tract [21]. The presence of males as stimulators also influences the sexual behavior of female cows. The company of male cattle can provide a biostimulant effect on female cows, which affects sexual maturity and can accelerate the emergence of estrus postpartum [22].

\section{Conclusion}

The estrus characters, including vulvar color, vulvar swelling, cervical mucus, vaginal temperature, cervical mucus $\mathrm{pH}$, and heat detector in the first and second artificial insemination, have no relationship. The regression models produced can be used but are less precise to estimate the relationship between estrus characters because the coefficient of determination shows a low influence.

Thank you to the Ministry of Research and Technology through the Indonesian Collaborative Research Program (PPKI) between University of Brawijaya, University of Gadjah Mada, and University of Sebelas Maret for providing funding for this research.

\section{References}

1. K. Kastalani, H. Torang, A. Kurniawan, Jurnal Ilmu Hewani Tropika (Journal of Tropical Animal Science), 8 (2020)

2. T. Susilawati, S. Rahayu, S. Udrayana, H. Sudarwati, E. Nugroho, American-Eurasian Journal of Sustainable Agriculture, 8 (2014)

3. J. Labetubun, I.P. Siwa, F. Reressy, Agrinimal, 8 (2020)

4. A. Rachmawati, Ismaya, B.P. Widyobroto, S. Bintara, T. Susilawati, Jurnal Ilmu-Ilmu Peternakan, 28 (2018)

5. T. Susilawati, L. Wahyudi, N. Isnaini and A.P.A. Yekti, The 6th International Seminar on Tropicel Production Integrated Approach in Developing Sustainable Tropical Animal Production 20 (2015)

6. H. Sudarwati, M.H. Natsir, V.M.A. Nurgiartiningsih. 2019. Statistika dan Rancangan Percobaan Penerapan Dalam Bidang Peternakan. Malang: UB Press.

7. D. Saputra, S. Sumartono, dan N. Humaidah, Dinamika Rekasatwa. 2(2018)

8. A. Murtaza, M.I.U.R. Khan, M. Abbas, N. Hameed, W. Ahmad, I. Mohsin and M.Z. Tahir, Animal reproduction science, 213 (2020)

9. F.A. Annashru, M. N. Ihsan, A. P. A. Yekti and T. Susilawati, Jurnal Ilmu-Ilmu Peternakan. 27 (2017)

10. M.N. Ihsan, Ilmu Reproduksi Ternak Dasar, Malang : UB Press. ISBN. 978-602896000-7 (2020)

11. K.K.Verma, S. Prasad, A. Kumaresan, T.K. Mohanty, S.S. Layek, T.K. Patbandha and S. Chand, Veterinary World, 7(2014)

12. F. Randi, M. McDonald, P. Duffy, A.K. Kelly and P. Lonergan, Theriogenology, 110 (2018)

13. A. Furqon, Dinamika Rekasatwa, 1 (2016)

14. T. Tsiligianni, G.S. Amiridis, E. Dovolou, I. Menegatos, S. Chadio, D. Rizos and A. 
Gutierrez-Adan, The Canadian Journal of Veterinary Research, 75 (2011)

15. W.A. Prasdini, S. Rahayu and M.S.Djati, International Journal of ChemTech Research, 7 (2015)

16. A. Rizki, P. Srianto, E. Suprihati, T. Sardjito, I. Ismudiono and M.A. Al Arif, Ovozoa, 8 (2019)

17. S.S. Layek, T.K. Mohanty, A. Kumaresan, K. Behera and S. Chand, Livestock Science, 152 (2013)

18. P.I. Sitaresmi, B.P. Widyobrot, S. Bintara and D.T. Widayati, IOP Conference Series: Earth and Environmental Science 387 (2019)

19. T.H. Tsiligiann, A. Karagiannidis, P. Brikas and P.H. Saratsis, Theriogenology, 55 (2001)

20. R.D. Frandson, W. L. Wilke and A. D. Fails, Anatomy And Physiology Of Farm Animal.7th Edition, Lippincottwilliams And Wilkins. Philadelphia (2009)

21. S.C. Scolari, S.G. Clark, R.V. Knox and M.A. Tamassia, Journal Of Swine Health And Production, 19 (2011)

22. E. Baliarti, M.H. Ali, T.S.M. Widi, D.E. Yulianto, B.A. Atmoko, H. Maulana, J. Effendhy, P.W. Prihandhini and D. Pamungkas, IOP Conference Series: Earth and Environmental Science, 465 (2011) 